\title{
Degradation and regeneration in mc-Si after different gettering steps
}

\author{
Annika Zuschlag*†, Daniel Skorka ${ }^{\dagger}$ and Giso Hahn \\ University of Konstanz, Department of Physics, 78457 Konstanz, Germany
}

\begin{abstract}
Light and elevated temperature induced degradation (LeTID) affects significantly the performance of multicrystalline (mc) Si passivated emitter and rear cell (PERC) solar cells, and underlying mechanisms of LeTID are still unknown. In this work LeTID and following regeneration of an industrial mc Si PERC solar cell is compared to differently processed minority charge carrier lifetime samples under illumination ( 1 sun) and elevated temperature $\left(75^{\circ} \mathrm{C}\right)$. LeTID on cell level reveals the same kinetics compared to lifetime samples. Varying the processing sequence has a significant effect on LeTID of life time samples. Ungettered samples with fired $\mathrm{SiN}_{\mathrm{x}}: \mathrm{H}$ surface passivation show a very strong LeTID and regeneration effect, with degradation kinetics being similar for all wafer areas irrespective of initial material quality. In contrast, regeneration sets in earlier in good quality areas. Differently gettered samples with lower contamination level than ungettered samples are less sensitive to LeTID, while overall degradation and regeneration behavior is strongly influenced by applied gettering sequences. Al gettered samples show a more pronounced degradation effect than $\mathrm{P}$ gettered samples, leading to the as sumption that $\mathrm{P}$ gettering is more effective in the reduction of LeTID sensitive defects. If the gettering step is less effective, in lifetime samples after degradation a beginning regeneration effect could be observed. A model is presented, describing LeTID in boron as well as gallium doped mc Si being based on impurities that can be gettered and redistributed during high temperature steps. Using this experimental approach helps to clarify the underlying mechanisms of LeTID and leads to a better understanding of degradation and regeneration mechanisms in mc Si. Copyright @ 2016 John Wiley \& Sons, Ltd
\end{abstract}

KEYWORDS

degradation; regeneration; multicrystalline; silicon; LeTID; gallium

*Correspondence

Annika Zuschlag, University of Konstanz, Department of Physics, 78457 Konstanz, Germany

E mail: annika.zuschlag@uni konstanz.de

${ }^{\dagger}$ These authors have contributed equally to this work.

\section{INTRODUCTION}

Light and elevated temperature induced degradation (LeTID) is a recently discovered effect on multicrystalline (mc) Si passivated emitter and rear cell (PERC) solar cells [1 3]. This effect can cause efficiency losses up to almost $10 \%$ rel. under illumination and elevated temperature [3] and cannot be attributed to standard $\mathrm{BO}$ complex forma tion or FeB pair dissociation [1]. In mc Si PERC solar cell concepts, a high diffusion length (or high minority charge carrier lifetime, respectively) can be used to further in crease cell efficiency to values $>21 \%$ [4]. In contrast, for standard full area Al back surface field cells the high bulk material quality does not lead to higher efficiencies be cause of the limiting recombination at the cell's rear side. Therefore, LeTID can be a showstopper when applying
PERC technology to $\mathrm{mcSi}$ for reaching higher efficiencies.

Also, a regeneration process after degradation has been observed by Kersten et al. [3], resembling the behavior known for BO correlated carrier induced degradation and regeneration [5 7], but on a totally different time scale (as already mentioned in [3]). The kinetics of degradation and regeneration is influenced by illumination and temper ature, while the underlying mechanisms causing the degra dation and regeneration of mc Si PERC solar cells are still unknown.

Recent investigations to clarify the parameters influenc ing the degradation and regeneration process are mainly based on solar cell or even on module level. Investigations on lifetime samples are still rare. Kersten et al. [3] have demonstrated the degradation of lifetime samples with 
different surface passivations, while Krauss et al. [8] used spatially resolved minority charge carrier lifetime maps to calculate a so called effective defect lifetime allowing an imaging of effective defects activated upon degradation. Bredemeier et al. [9] have recently published a lifetime study on the influence of different firing temperatures on the lifetime degradation and regeneration.

Studying LeTID on solar cell level allows evaluation of the effect directly by current voltage measurements with all effects present (metallization, current distribution in the cell, etc.). The advantage of lifetime studies is that a more flexible design of experiment is possible (e.g. regard ing applied process steps/sequences), which can be useful to identify further parameters influencing degradation and regeneration behavior. This work demonstrates minority charge carrier lifetime degradation and regeneration on $\mathrm{mc}$ Si wafer level. The different gettering sequences result in different contamination levels and impurity distribu tions. Because of its flexibility, the approach chosen in this contribution based on lifetime samples allows to gain a more detailed fundamental understanding of the underly ing mechanisms of LeTID.

\section{EXPERIMENTAL}

An industrial mc Si PERC solar cell and several lifetime samples are investigated to compare the degradation and regeneration process on solar cell and lifetime level. The investigation of mc Si PERC solar cells allows one to link and compare the results to previously published results on LeTID, while the studies on differently processed lifetime samples are focused on identification of process steps influencing degradation and regeneration behavior of $\mathrm{mc}$ Si material.

The mc Si wafers (1.5 $\Omega \mathrm{cm}$ boron doped) used for life time samples originate from the same mc Si ingot and the same ingot height as the investigated standard industrial $156 \times 156 \mathrm{~mm}^{2} \mathrm{mc}$ Si PERC solar cell, leading to a compa rable material quality of the initial material. Sister wafers $\left(5 \times 5 \mathrm{~cm}^{2}\right)$ with comparable grain and defect structure were used to compare the influence of different process steps on degradation and regeneration behavior of the life time samples. A scheme of the applied process sequences is given in Figure 1. The wafers were chemically etched to remove saw damage. Sample A was not further proc essed, and only a surface passivation was realized by firing of a plasma enhanced chemical vapor deposition (PECVD) $\mathrm{SiN}_{\mathrm{x}}$ :H layer. For samples B, C, and D, different gettering sequences were applied. Sample B was gettered by a $\mathrm{POCl}_{3}$ diffusion $(55 \Omega / \square)$, while sample $\mathrm{C}$ was gettered by screen printing and firing of an $\mathrm{Al}$ contact on the backside. $\mathrm{P}$ and $\mathrm{Al}$ gettering was combined in case of sample D. Additionally, a PECVD $\mathrm{SiN}_{\mathrm{x}}: \mathrm{H}$ layer was ap plied to all bare wafer surfaces to protect the wafers from contamination during the following firing step. Afterwards, the $\mathrm{SiN}_{\mathrm{x}}: \mathrm{H}$ layers as well as the $\mathrm{Al}$ back surface field and the emitter were removed. The samples were surface passivated again by firing (measured wafer temperature: $730^{\circ} \mathrm{C}$ ) of a PECVD $\mathrm{SiN}_{\mathrm{x}}: \mathrm{H}$ layer (same deposition pa rameters as before) leading to an additional hydrogenation of the investigated samples.

For degradation, lifetime samples as well as the solar cell are held at a temperature of approx. $75^{\circ} \mathrm{C}$ on a hot plate under illumination with halogen lamps $(0.9 \pm 0.05$ suns for lifetime samples, $1 \pm 0.05$ sun for the solar cell).

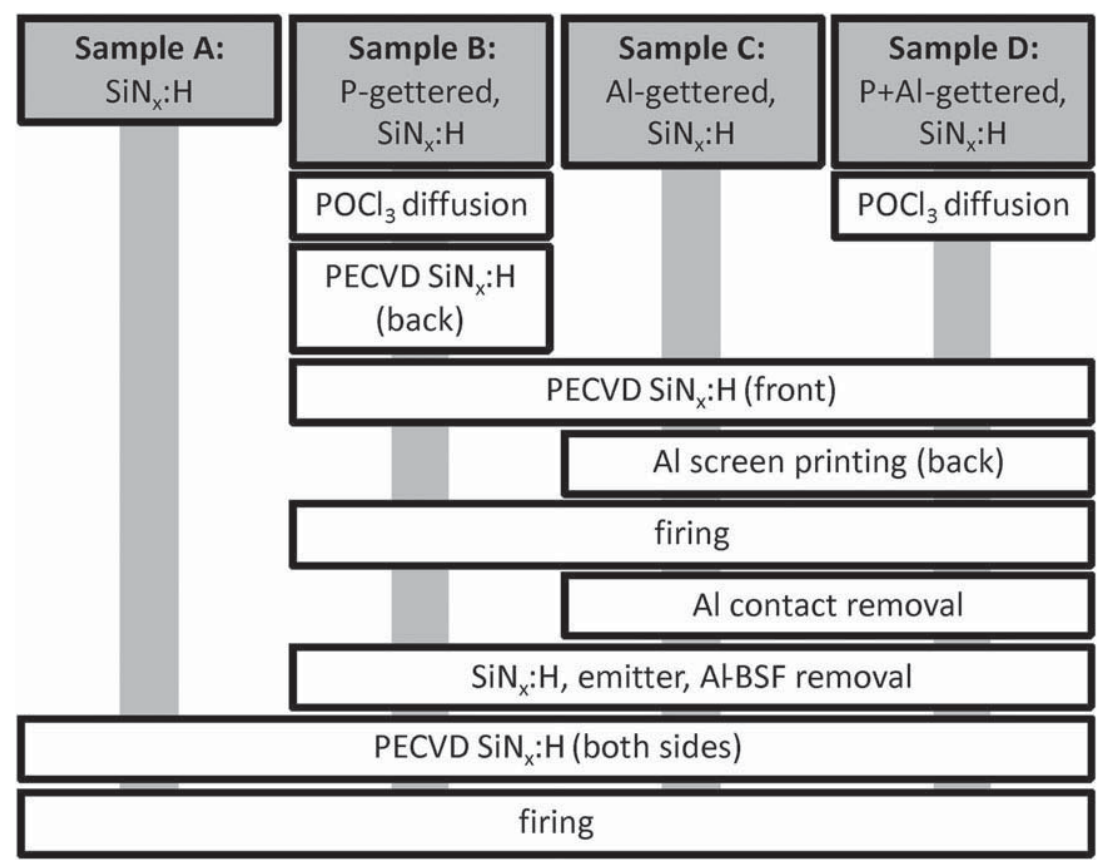

Figure 1. Process sequence of the investigated lifetime samples. 
During the degradation and regeneration process, the solar cell is characterized in situ by automated open circuit volt age $\left(\mathrm{V}_{\mathrm{oc}}\right)$ measurements. For lifetime samples, effective minority charge carrier lifetime $\left(\tau_{\text {eff }}\right)$ is measured repeti tively by the fast and self calibrated time resolved photoluminescence imaging (TR PLI) method [10,11] at room temperature, resulting in a series of spatially resolved lifetime maps for each sample over degradation time. The first $\tau_{\text {eff }}$ data point of the lifetime samples is measured di rectly (approx. $2 \mathrm{~min}$ ) after the last firing step consistent with standard solar cell characterization, which usually takes place directly after firing in industrial production lines.

For a statistically relevant analysis of areas differing in material quality, the TR PLI lifetime maps of each sample over time are aligned and an array of 2500 areas (each $150 \times 150 \mu \mathrm{m}^{2}$ in size) at fixed positions is distributed over the TR PLI lifetime map of the $5 \times 5 \mathrm{~cm}^{2} \mathrm{mc}$ Si samples to get good statistics. Average $\tau_{\text {eff }}$ values within these areas are extracted over degradation time and further analyzed. This method allows tracking of changes in $\tau_{\text {eff }}$ of different sample areas under degradation conditions. The advantage of this approach is that the spatially resolved information of $\tau_{\text {eff }}$ maps over degradation time can be easily displayed. The $\tau_{\text {eff }}$ data for each $150 \times 150 \mu \mathrm{m}^{2}$ area on the samples is plotted over time and coded by a rainbow color bar based on the areas' lifetime values at the beginning of the degra dation experiment.

\section{RESULTS AND DISCUSSION}

Continuously measured $\mathrm{V}_{\mathrm{oc}}$ data of an industrial mc Si PERC solar cell are shown in Figure 2. It is obvious that this PERC solar cell is LeTID sensitive and the $\mathrm{V}_{\mathrm{oc}}$ data shows a degradation of approx. $12 \%$ rel. after $200 \mathrm{~h}$ followed by regeneration as also observed previously, for example, in [3]. After $1500 \mathrm{~h}$, the solar cell recovers almost completely. As already discussed in, for example, $[1,3]$ the

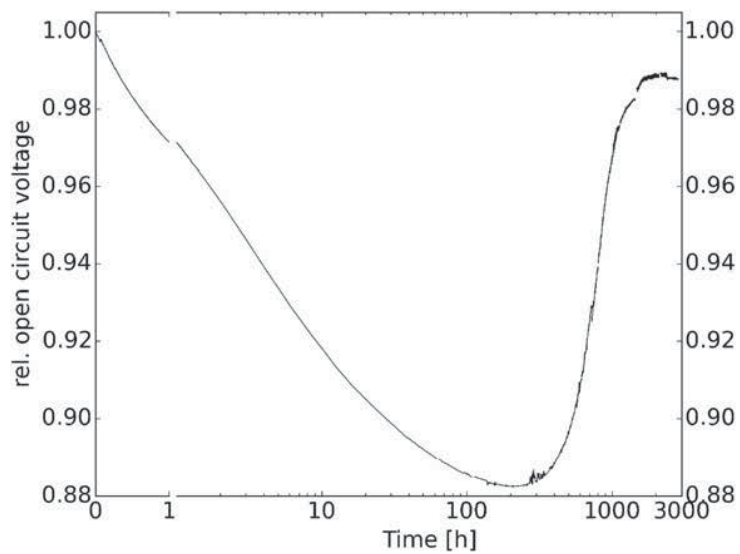

Figure 2. Continuously measured $\mathrm{V}_{\mathrm{oc}}$ data of an industrial mc $\mathrm{Si}$ PERC solar cell showing degradation and regeneration (first $1 \mathrm{~h}$ : linear scale, afterwards: log scale). observed degradation and regeneration cannot be fully ex plained by $\mathrm{BO}$ correlated degradation or $\mathrm{FeB}$ pair dissoci ation processes.

Figure 3 shows the behavior of harmonic average $\tau_{\text {eff }}$ for the four differently processed lifetime sister samples A D. All samples show fast degradation within the first minutes which could be attributed to $\mathrm{FeB}$ and/or $\mathrm{BO}$ based degradation effects. After longer periods, significant differences are measured for samples A, B, C, and D re garding the strength of the degradation, the range of mini mum and maximum $\tau_{\text {eff }}$ in dependence of the degradation state, and the regeneration behavior which can be clearly observed for sample A and also slightly for samples C and D. The ungettered sample A shows the strongest deg radation but also the strongest relative regeneration. Ap plied gettering steps (samples B, C, D) reduce the degradation effect significantly. While samples with $\mathrm{Al}$ gettering step (sample $\mathrm{C}$ and $\mathrm{D}$ ) show a lifetime minimum because of degradation, no clear minimum could be ob served in case of the only P gettered sample B.

First investigations on a set of gallium doped $\mathrm{mc}$ Si life time samples with and without $\mathrm{P}$ gettering step result in a slower degradation at the beginning of the experiment, most probably because of missing $\mathrm{BO}$ or $\mathrm{FeB}$ induced degradation, strengthening the hypothesis that other impu rities are responsible for the so called LeTID effect, as al ready observed by Ramspeck et al. [1] on solar cell level. Also for gallium doped lifetime samples, the degradation in ungettered samples is more pronounced compared to $P$ gettered samples [12]. It is still unclear at this moment whether LeTID can be avoided by replacing B with $\mathrm{Ga}$ doping as the concentration of $\mathrm{B}$ in the investigated $\mathrm{Ga}$ doped samples has not been determined yet.

A comparison to the degradation behavior of the solar cell shows that the maximum degradation level for average $\tau_{\text {eff }}$ in Figure 3 and the $V_{o c}$ value in case of the solar cell (Figure 2) is reached after approximately the same

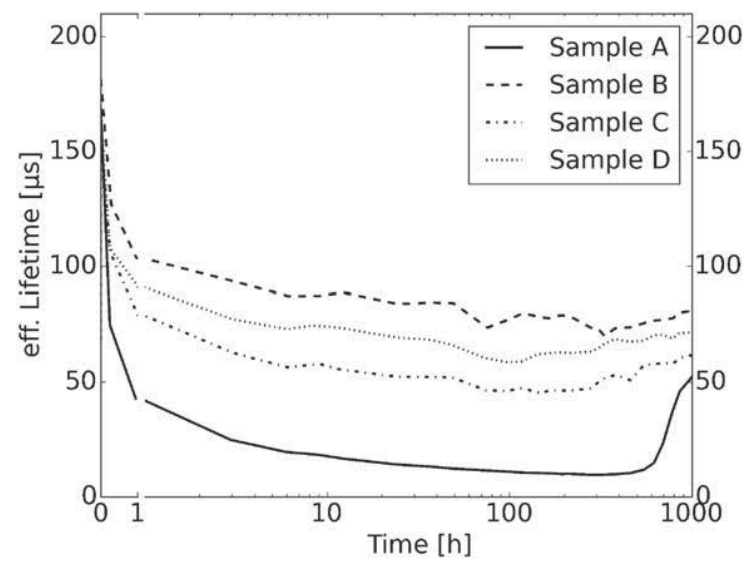

Figure 3. Harmonic average $\tau_{\text {eff }}$ data for differently processed mc Si wafers. Degradation and regeneration behavior of lifetime samples can be strongly influenced by previously applied gettering sequences (first $1 \mathrm{~h}$ : linear scale, afterwards: log scale). 
degradation time using (almost) the same illumination level and elevated temperature. This leads to the assump tion that the underlying degradation and regeneration effect can be studied either on lifetime or on solar cell level.

The disadvantage of average $\tau_{\text {eff }}$ analyses is that infor mation on local lifetime distribution measured by spatially resolved TR PLI gets lost. Figure 4 shows exemplarily $\tau_{\text {eff }}$ maps of sample A at three different states: at the beginning of the degradation, in the degraded state, and during the re generation process. The whole series of these spatially re solved TR PLI measurements has been aligned and analyzed as described above. Further analyses of the degra dation and regeneration behavior will be discussed based on Figure 5. Each single line (guides to the eye connecting single data points) in Figure 5 represents one of the 2500 small $150 \times 150 \mu \mathrm{m}^{2}$ areas on the lifetime samples.

The applied color code, based on the initial lifetime of each sample at the beginning of the experiment, shows that for all four samples the relative $\tau_{\text {eff }}$ distribution is main tained during the experiment, which means that indepen dently of the applied process sequence, sample areas with the highest initial $\tau_{\text {eff }}$ show also the highest $\tau_{\text {eff }}$ at the max imum degradation level as well as during the regeneration process. This holds true even if the range of lifetime is narrowed down during degradation or is spread again dur ing regeneration.

In case of sample A (not gettered, Figure 5a), a very strong and fast degradation of the whole sample is ob served. As already mentioned for harmonic average $\tau_{\text {eff }}$ data, $\mathrm{FeB}$ and/or $\mathrm{BO}$ induced degradation could be in volved additionally to LeTID in the first few minutes, but the degradation behavior cannot be fully explained based on $\mathrm{FeB}$ and/or BO induced dynamics. Especially sample areas of higher initial $\tau_{\text {eff }}$ suffer from the applied degrada tion conditions, and relative degradation in these areas is stronger than in sample areas with lower initial $\tau_{\text {eff }}$.

The initial lifetime distribution of sample A (approx. $30350 \mu$ s) narrows down to a very small range (approx. $530 \mu \mathrm{s})$ at maximum degradation level. This strong degra dation even in areas of initially high $\tau_{\text {eff }}$ could be explained by an approximately homogenous formation of defects over the wafer area. The degradation kinetics is very simi lar in all sample areas, independently of the initial $\tau_{\text {eff. }}$ Af ter approximately $300 \mathrm{~h}$, a regeneration process sets in, with regeneration in areas with higher initial $\tau_{\text {eff }}$ (red lines) starting significantly earlier than in areas of lower initial $\tau_{\text {eff }}$, indicated by a black dashed line in Figure $5 \mathrm{a}$, and also by the inlay and the differently colored arrows in Figure 5a. The earlier onset of regeneration in areas of initially high $\tau_{\text {eff }}$ is the reason why in these regions the minimal visible $\tau_{\text {eff }}$ level is reached earlier compared to areas with lower initial $\tau_{\text {eff. }}$. But it has to be assumed that initially good $\tau_{\text {eff }}$ areas show very similar degradation kinetics (time con stants) than initially poor $\tau_{\text {eff }}$ areas. The different starting points for observable regeneration are remarkable, espe cially regarding the narrow $\tau_{\text {eff }}$ distribution at around $200 \mathrm{~h}$. The different regeneration behavior leads to the as sumption that the regeneration is not only a reversal of the first degradation reaction and that the underlying mecha nism is more complex. It is not yet clear whether $\tau_{\text {eff }}$ re covers completely.

Up to now, it is not yet clear whether the observed deg radation within the first hours under illumination originates from bulk defect formation or changes in surface passiv ation quality. Therefore, an additional sample is prepared exactly like sample A, and the same degradation condi tions are applied leading to a comparable degradation be havior as observed for sample A. After approx. $300 \mathrm{~h}$, the $\mathrm{SiN}_{\mathrm{x}}: \mathrm{H}$ surface passivation layer is etched back and a chemical surface passivation (iodine ethanol, [13]) is ap plied. The previously measured spatial distribution of low $\tau_{\text {eff }}$ values after $300 \mathrm{~h}$ degradation is thereby confirmed, verifying that the observed strong degradation is a bulk ef fect and not related to changes in $\mathrm{SiN}_{\mathrm{x}}: \mathrm{H}$ surface passiv ation quality. There are hints that $\mathrm{SiN}_{\mathrm{x}}: \mathrm{H}$ surface passivation quality slightly decreases after several hundred hours under illumination at $75^{\circ} \mathrm{C}$. This might influence the long time regeneration behavior $(>1000 \mathrm{~h})$, but cannot ex plain the observed degradation.

The P gettered sample B (Figure 5b) shows only a slight lifetime reduction within the first minutes under illu mination at elevated temperature and is therefore signifi cantly less sensitive to LeTID than sample A. In contrast to the ungettered sample A discussed above, the $\tau_{\text {eff }}$ range (approx. $40360 \mu \mathrm{s}$ ) is only slightly narrowed down and stays nearly constant during the experiment. The data shows no clear maximum degradation level and no regen eration, and $\tau_{\text {eff }}$ stays almost constant in the different
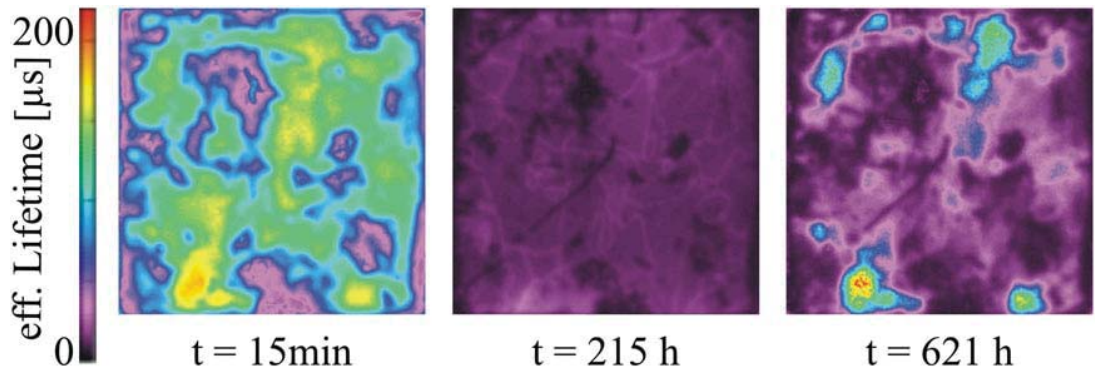

Figure 4. Spatially resolved TR PLI measurements of sample A at the beginning of the applied degradation process, in the degraded state, and during regeneration. [Colour figure can be viewed at wileyonlinelibrary.com] 

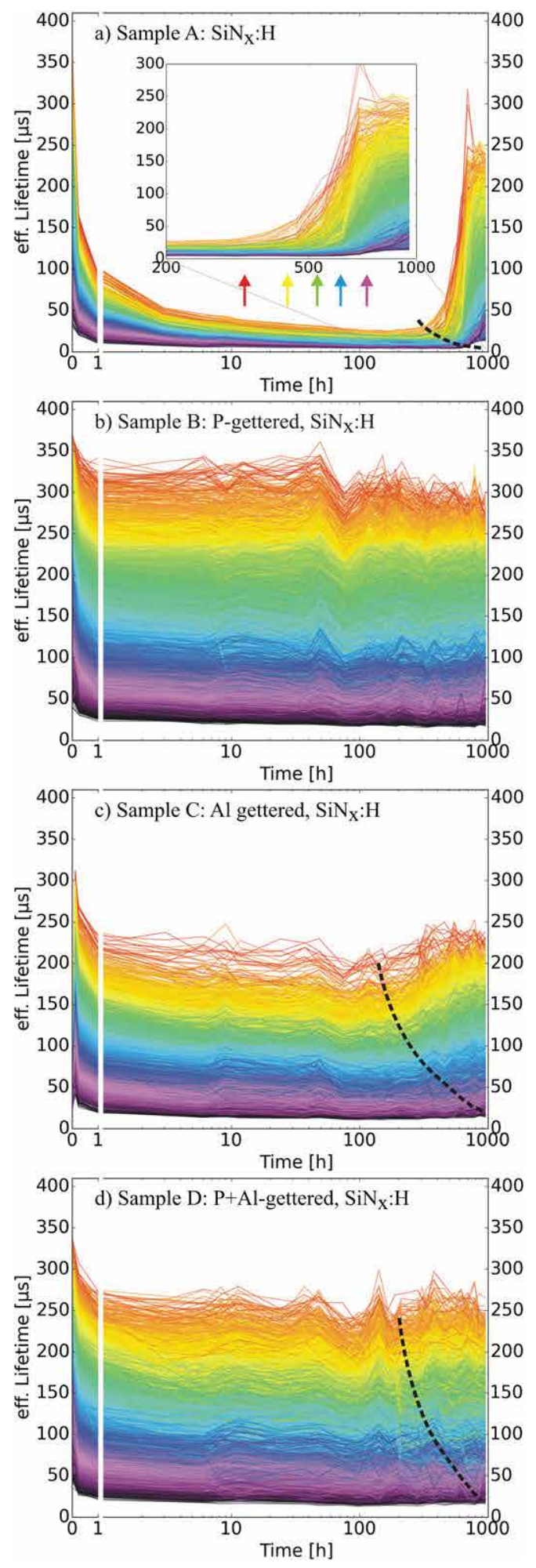

Figure 5. $\tau_{\text {eff }}$ of differently processed sister wafers (first $1 \mathrm{~h}$ : lin ear scale, afterwards: log scale). Each line in the graph represents an area of $150 \times 150 \mu^{2}$ in the spatially resolved TR PLI lifetime measurements and is color coded to its value at the beginning of degradation. Black dashed lines indicate beginning regenera tion. [Colour figure can be viewed at wileyonlinelibrary.com] sample areas. Areas of lower initial lifetime after gettering show more relative degradation than areas of higher mate rial quality.

In case of sample $\mathrm{B}$, the repetition of the PECVD $\mathrm{SiN}_{\mathrm{x}}$ : $\mathrm{H}$ deposition and firing as shown in Figure 1 has been per formed to get a similar temperature load compared to the Al gettered samples $\mathrm{C}$ and $\mathrm{D}$. If the degradation conditions are applied to a $\mathrm{P}$ gettered sample after the first firing of the $\mathrm{SiN}_{\mathrm{x}}: \mathrm{H}$ passivation layer, comparable results to sample B are observed on an additional wafer set with comparable initial material quality. If the investigated sample area is strongly dominated by extended defect clusters of lower material quality, a more pronounced degradation could be observed also for $\mathrm{P}$ gettered samples (not shown). This hints towards a complex interaction of gettering efficiency on local defect structures (as seen, e.g. in [14]) and the ef fect on degradation behavior.

In contrast to sample $\mathrm{B}$, the $\mathrm{Al}$ gettered sister sample $\mathrm{C}$ shows a significantly different degradation and regen eration behavior. Overall degradation and regeneration behavior is closer to the ungettered sample A than to the $\mathrm{P}$ gettered sample B. As observed for sample A, the $\mathrm{Al}$ gettered sample $\mathrm{C}$ shows also a maximum degra dation level and a narrowing of the $\tau_{\text {eff }}$ range, but by far not as significant as sample $\mathrm{A}$. The regeneration process again sets in earlier for sample areas with higher initial $\tau_{\text {eff }}$ as indicated by a black dashed line in Figure 5c.

For sample D, both $\mathrm{Al}$ and $\mathrm{P}$ gettering were applied. Degradation is stronger than in case of sample B but less pronounced compared to sample $\mathrm{C}$. Also a beginning re generation can be hinted as indicated by a black dashed line in Figure 5d. Therefore, the degradation and regenera tion behavior of sample D is a mix of the observed results of the only $\mathrm{P}$ gettered sample $\mathrm{B}$ and the only $\mathrm{Al}$ gettered sample C.

Because of the expected different contamination level or impurity distribution of the gettered samples B, C, and D compared to sample A, it is assumed that impurities strongly influence the degradation and regeneration behav ior. A P gettering step seems to be more efficient to re move degradation sensitive defects than an $\mathrm{Al}$ gettering step. After $\mathrm{P}$ gettering, each following temperature step leads to a redistribution of (internally or externally) gettered degradation relevant defects. Besides firing steps, the temperature loads during surface passivation process ing steps have to be taken into account. In [15], P gettered lifetime samples with different surface passivation treat ments (including stack systems like $\mathrm{AlO}_{\mathrm{x}}+\mathrm{SiN}_{\mathrm{x}}: \mathrm{H}$ and a thermal $\mathrm{SiO}_{2}$ covered by $\mathrm{SiN}_{\mathrm{x}}: \mathrm{H}$ ) are compared. It can be demonstrated that for samples with additional temperature load after the $\mathrm{P}$ gettering step a more pronounced LeTID and following regeneration occurs. The effect is most pro nounced for a thermal $\mathrm{SiO}_{2}$ step with the highest tempera ture load, followed by samples with additional $\mathrm{AlO}_{\mathrm{x}}$ deposition, while samples with single PECVD $\operatorname{SiN}_{\mathrm{x}}: \mathrm{H}$ layer show a similar behavior as discussed above for sam ple B. 
It has to be mentioned that the firing conditions (set pa rameters) are kept constant but lead to a slightly different temperature load of the bulk material during the first firing step for sample B compared to samples $\mathrm{C}$ and $\mathrm{D}$ because of the screen printed $\mathrm{Al}$ back side of samples $\mathrm{C}$ and $\mathrm{D}$. The lower wafer temperature of the $\mathrm{P}$ gettered sample $\mathrm{B}$ com pared to the additionally $\mathrm{Al}$ gettered sample $\mathrm{D}$ during the first firing step may lead to a slightly different and less LeTID sensitive impurity distribution for sample B. As shown in [9], different firing temperatures generally have an influence on degradation behavior.

The earlier onset of regeneration for LeTID in areas of higher $\tau_{\text {eff }}$ resembles the behavior of regeneration of BO correlated degradation. There it could be shown that a higher excess charge carrier density $\Delta \mathrm{n}$ in the Si bulk leads to a faster regeneration process $[6,7]$. Interestingly, the on set of LeTID regeneration starts earlier in the best quality areas of sample C (after approx. $200 \mathrm{~h}$ ) having higher $\tau_{\text {eff }}$ as compared to the best areas of sample A (after approx. $400 \mathrm{~h}$ ) as indicated by the dashed line in Figure 5, with sample D lying in between. Note that all samples are sister wafers with comparable extended defect structure and sim ilar surface passivation quality. As higher $\tau_{\text {eff }}$ leads to higher $\Delta \mathrm{n}$ for constant illumination, this leads to the con clusion that $\Delta \mathrm{n}$ might play a decisive role for LeTID regeneration.

The next step in the analogy between regeneration for LeTID and $\mathrm{BO}$ regeneration would be the assumption that hydrogen plays an important role, too. As shown for BO regeneration, the presence of hydrogen in the $\mathrm{Si}$ bulk seems to be a prerequisite for the regeneration to occur and its concentration influences the regeneration kinetics [16]. The significantly different time scale could, for exam ple, be explained by the different effective diffusion con stant of hydrogen at relatively low temperatures in $\mathrm{mc} \mathrm{Si}$ compared to monocrystalline Si because of trapping (trap assisted diffusion). But this hypothesis still has to be con firmed in future experiments.

\section{MODEL FOR LETID AND CONSEQUENCES}

Effective gettering seems to be a key component to minimize the impact of LeTID in mc Si. Under the as sumption that degradation in $\mathrm{mc} \mathrm{Si}$ at longer timescales $\left(>1 \mathrm{~h}\right.$ at $75^{\circ} \mathrm{C}$ ) is triggered by the concentration of a spe cific impurity (or a mix of impurities) that is more or less homogeneously distributed over the wafer area, a first rough model can be introduced.

In areas of good material quality (low density of ex tended defects like grain boundaries and/or dislocations) where gettering is very effective, LeTID can be suppressed very effectively in lifetime samples. In contrast, in areas of poorer crystal quality (more extended defects), gettering is less effective as impurities might also be present in the form of precipitates that are harder to getter externally, be cause they first have to be dissolved and dissolved impurities might be gettered internally again at extended defects. This can be seen qualitatively for sample B (Figure 5b), where good sample areas show less relative degradation than areas of poorer quality, and is also ob served in [17] for a different set of samples and different processing sequences.

A consequence of this first model is that high tempera ture steps after the gettering steps might lead to a redistri bution of gettered impurities from their initial gettering sites (e.g. the emitter region, internal gettering sites). In deed, it could be observed that a thermal oxidation step carried out after a P gettering step "reactivates" LeTID and following regeneration [15].

The model presented here is most probably not yet able to explain LeTID and regeneration behavior in all its facets, but gettering seems to play an important role and should be considered in further experiments to deepen the understanding of LeTID in mc Si.

The regeneration observed for LeTID might be related to the presence of hydrogen in the Si bulk, being more mo bile under illumination, maybe because of the change of its charge state $[18,19]$.

Another consequence from the proposed model is that a back to back P diffusion process as normally carried out in industrial cell processing might lead to a stronger LeTID effect because of the less effective gettering.

\section{SUMMARY AND OUTLOOK}

The influence of different solar cell gettering steps on LeTID and regeneration has been demonstrated using spa tially resolved data from TR PLI. It could be shown that the behavior of lifetime samples resembles the behavior of PERC solar cells fabricated from the same mc Si mate rial and can therefore be regarded as relevant for PERC type solar cell processing.

The applied data processing allows the analysis of dif ferent sample areas over degradation time in a statistically relevant way and is not limited to selected sample areas or the comparison of only two degradation or regeneration states.

For ungettered samples, it could be shown that degrada tion kinetics are very similar for all sample areas irrespec tive of their initial quality, while regeneration sets in first in good quality areas. Gettering drastically reduces LeTID while the strength of degradation and the following regen eration is influenced by the applied gettering sequence. $\mathrm{P}$ gettering is more efficient than $\mathrm{Al}$ gettering for removing or restructuring LeTID sensitive defects, but gettering effi cacy depends also on the underlying crystal defect structure.

It could be shown that LeTID is a bulk degradation ef fect occurring in boron as well as gallium doped mc Si. Therefore, it cannot be attributed to $\mathrm{BO}$ or $\mathrm{FeB}$ related de fects alone.

The influence of the different gettering sequences on the degradation and regeneration process leads to the 
conclusion that the concentration and distribution of (metal) impurities play a major role for LeTID and regen eration. Therefore, the industrial PERC solar cell process ing sequence should be optimized concerning effective gettering and avoidance of redistribution of gettered impu rities during following temperature steps. In addition, a high concentration of hydrogen in the correct binding state might help to speed up the regeneration process (as for BO regeneration [20]), when LeTID cannot be avoided completely.

This long time experiment is still running to further an alyze the regeneration process and the longtime stability of the regenerated state and the surface passivation. Also, ad ditional lifetime samples with further process sequences are under investigation.

\section{ACKNOWLEDGEMENTS}

The authors would like to thank Lisa Mahlstaedt and David Sperber for help during sample processing and Axel Herguth for help during sample characterization and fruit ful discussions. Part of this work was funded by the Ger man Federal Ministry of Economic Affairs and Energy and by industrial partners within the research project "SolarLIFE" (0325763B) and within 0325581. The content is the responsibility of the authors.

\section{REFERENCES}

1. Ramspeck K, Zimmermann S, Nagel H, Metz A, Gassenbauer Y, Birkmann B, Seidl A. Light induced degradation of rear passivated mc Si solar cells. Pro ceedings 27th EU PVSEC, 2012; 861 865, DOI: 10.4229/27thEUPVSEC2012 2DO.3.4

2. Fertig F, Krauss K, Rein S. Light induced degradation of PECVD aluminium oxide passivated silicon solar cells. Physica Status Solidi (RRL) 2014; 9(1): 4146. DOI:10.1002/pssr.201409424.

3. Kersten F, Engelhart P, Ploigt HC, Stekolnikov A, Lindner T, Stenzel F, Bartzsch M, Szpeth A, Petter K, Heitmann J, Müller J. Degradation of multicrystalline silicon solar cells and modules after il lumination at elevated temperature. Solar Energy Ma terials \& Solar Cells 2015; 124: 8386. DOI:10.1016/j.solmat.2015.06.015.

4. Green MA, Emery K, Hishikawa Y, Warta W, Dunlop ED. Solar cell efficiency tables (version 47). Progress in Photovoltaics: Research and Applications 2016; 24(1): 3 11. DOI:10.1002/pip.2728.

5. Herguth A, Schubert G, Kaes M, Hahn G. A new ap proach to prevent the negative impact of the metastable defect in boron doped $\mathrm{Cz}$ silicon solar cells. Proceed ings 4th WCPEC, 2006; 940943.
6. Herguth A, Schubert G, Kaes M, Hahn G. Investiga tions on the long time behavior of the metastable boron oxygen complex in crystalline silicon. Progress in Photovoltaics: Research and Applications 2008; 16: 135 140. DOI:10.1002/pip.779.

7. Herguth A, Hahn G. Kinetics of the boron oxygen re lated defect in theory and experiment. Journal of Ap plied Physics 2010; 108: 114509 1 7. DOI:10.1063/ 1.3517155 .

8. Krauss K, Fertig F, Menzel D, Rein S. Light induced degradation of silicon solar cells with aluminium oxide passivated rear side. Energy Procedia 2015; 77: 599 606. DOI:10.1016/j.egypro.2015.07.086.

9. Bredemeier D, Walter D, Herlufsen S, Schmidt J. Life time degradation and regeneration in multicrystalline silicon under illumination at elevated temperature. AIP Advances 2016; 6: 0351191 8. DOI:10.1063/ 1.4944839 .

10. Kiliani D, Micard G, Steuer B, Raabe B, Herguth A, Hahn G. Minority charge carrier lifetime mapping of crystalline silicon wafers by time resolved photoluminescence imaging. Journal of Applied Phys ics 2011; 110: 054508 1 7. DOI:10.1063/1.3630031.

11. Kiliani D, Herguth A, Micard G, Ebser J, Hahn G. Time resolved photoluminescence imaging with elec tronic shuttering using an image intensifier unit. Solar Energy Materials \& Solar Cells 2012; 106: 5559. DOI:10.1016/j.solmat.2012.05.042.

12. Zuschlag A, Skorka D, Hahn G. Comparison of degra dation and regeneration kinetics in differently doped mc Si materials. To be published.

13. Pollock K, Junge J, Hahn G. Detailed investigation of surface passivation methods for lifetime measurements on silicon wafers. IEEE Journal of Photovoltaics 2012; 2(1): 1 6. DOI:10.1109/jphotov.2011.2174337.

14. Gindner S, Karzel P, Herzog B, Hahn G. Efficacy of phosphorus gettering and hydrogenation in multicrystalline silicon. IEEE Journal of Photovoltaics 2014; 4(4): $10631070 . \quad$ DOI:10.1109/ JPHOTOV.2014.2322276.

15. Zuschlag A, Skorka D, Hahn G. Degradation and re generation analysis in mc Si. Proceedings 43rd IEEE PVSC, 2016, in press.

16. Wilking S, Herguth A, Hahn G. Influence of hydrogen on the regeneration of boron oxygen related defects in crystalline silicon. Journal of Applied Physics 2013; 113: 1945031 6. DOI:10.1063/1.4804310.

17. Skorka D, Zuschlag A, Hahn G. Spatially resolved degradation and regeneration kinetics in $\mathrm{mc} \mathrm{Si}$. Pro ceedings 32nd EU PVSEC, 2016; 643 646, DOI: 10.4229/EUPVSEC20162016 2AV.1.26

18. Hamer P, Hallam B, Wenham S, Abbott M. Manipula tion of hydrogen charge states for passivation of $p$ type 
wafers in photovoltaics. IEEE Journal of Photovol taics 2014; 4(5): 1252 1260. DOI:10.1109/ JPHOTOV.2014.2339494.

19. Sun C, Rougieux FE, Macdonald D. A unified ap proach to modelling the charge state of monatomic hy drogen and other defects in crystalline silicon. Journal of Applied Physics 2015; 117: 045702. DOI:10.1063/ 1.4906465.
20. Wilking S, Herguth A, Hahn G. Influence of bound hy drogen states on BO regeneration kinetics and conse quences for high speed regeneration processes. Solar Energy Materials \& Solar Cells 2014; 131: 28. DOI:10.1016/j.solmat.2014.06.027. 